\title{
Church of Uganda Retirement Policy Funding and its Implementation: A Case of Church of Uganda Buganda Dioceses
}

\author{
Paul Kakooza* and Emmanuel Kiwumulo
}

Istanbul Aydin University, Turkey

DOI: $10.36347 /$ sjahss.2021.v09i02.001

| Received: 18.01.2021 | Accepted: 01.02.2021 | Published: 09.02.2021

*Corresponding author: Paul Kakooza

Abstract

Original Research Article

This paper analyzed Church of Uganda retirement policy funding and implementation a case of CoU Buganda dioceses with the objectives of analyzing $\mathrm{CoU}$ the relationship between funding and policy implementation and. examine the effect of funding on policy implementation. In $2010 \mathrm{CoU}$ sanctioned her retirement policy with the objective of improving the welfare of the retired clergy, albeit this implementation, funding has remained a major impediment to an effective implementation of the policy. This paper employed a mixed methodological approach of both quantitative and qualitative nature for data collection and analysis. Findings revealed that (a) Dioceses in Buganda region had a low commitment as far as funding of retirement policy is concerned, this was confirmed of the descriptive analysis that portrayed that the total (Mean $=2.7, \mathrm{SD}=1.1$ ) implying that effective retirement policy implementation could not be realised with just a fair contribution from dioceses and that the implementation had an average rate of (Mean $=3.08, \mathrm{SD}=1.30)$ according to the descriptive analysis The findings therefore concluded that CoU retirement policy implementation was still wanting due to inadequate funding which exposes the retired clergy to myriads of life challenges and that $\mathrm{CoU}$ needs to come up with funding strategies in order to facilitate effective implementation of the policy.

Keywords: Retirement policy funding, implementation, Church of Uganda.

Copyright $\left({ }^{\circ} 2021\right.$ The Author(s): This is an open-access article distributed under the terms of the Creative Commons Attribution 4.0 International License (CC BY-NC 4.0) which permits unrestricted use, distribution, and reproduction in any medium for non-commercial use provided the original author and source are credited.

\section{INTRODUCTION}

Social security and employer pensions have traditionally been important sources of replacement income in retirement coupled with health insurance which otherwise would be quite expensive, these public and private pension plans help make retirement a viable economic option for many [1]. Without such economic inducements, retirement would never be complete. While retirement did not become normative in U.S society until after the passage of social security and legislation encouraging company pensions, Pillemer, Moen, Glasgow, \& Wethington, [2] identified a trend for retirement before the period. During the great depression, a large number of retirees relied on their own finances to support them, rather than income from family members, as had been common for people who had withdrawn from the labor force at the end of the 1800 s and the beginning of the 1900s. It then became imperative for employee organisations to fund social security schemes in order to safe guard the lives of the retirees.
Ekerdt, De Viney, \& Kosloski [3] examined whether organization context provides or reinforces age at norms for retirement, this is because the age between 62 and above is vulnerable. The morbidity among the retirees is high characterised with chronical diseases like diabetes, hypertension and others. These diseases are not only complicated to handle but they are also expensive in terms of treatment. The employees' eligibility to pension benefits including medical insurance schemes becomes an alternative especially when the person retires. However, this can only be true when the pensions are well funded.

Since the early 1970s, retirement has occurred increasingly because of a desire to leave work, while poor health and layoffs account for a much smaller proportion of reasons for retiring $[4,5]$.

Thus, older adults' exiting from the work force throughout the $20^{\text {th }}$ century increased due to a desire to retire, which is indicative of the norm of retirement as an entitlement and a leisure period of life [6], rather 
than people's declining physical or mental capabilities to work (perceived or real). This suggestion show retirement has remained normative despite many changes in society. Retirement has come to be viewed as a time of life that is full of nonproductive and worthless as was once perhaps true. This shift became possible because of remarkable improvements in health and health care in the $20^{\text {th }}$ century. So many adults in the half of the centuries reached retirement age in good health. In addition, retirement became more of a possibility with the advent of social security and private pensions which financially support retirement.

Funding of retirement policies is very critical since most people retire without or with minimal retirement readiness as emphasized by Moore, Robson \& Laurin [7]. Retirement readiness typically refers to being financially prepared for retirement, or the degree to which an individual is on target to meet his or her retirement-income, so that the standard of living enjoyed while working would be maintained after retirement. Although retirement readiness depends on each person's financial situation, many financial experts believe that retirees need between two-thirds and threequarters of their pre-retirement income to maintain the same standard of living in retirement as they enjoyed when they were working [7]. It is not a simple task for an employee to make such savings without support from the employer and usually employees lack that discipline thus a need for formal retirement policies.

This is the reason why Mercer, [8]; Amaike, [9]; and Obashoro [10] contend that when retirement policies are poorly funded, implementation becomes a challenge, and thus it results into both a drop in the living standards of the retired people and complications that directly threaten standards of living. The notion further articulated by the theory of continuity based on the premise that older adults who preserve a similar lifestyle in retirement as they previously had will have a higher level of psychological well-being [11]. Retirement usually sets in with fundamental changes in form of income, social connectivity and other benefits that lead to a change of lifestyle of a retiree on this reason why retirees who are able to maintain a previous lifestyle while still working.

This is because retirees are expected to depend on their retirement benefits after working. This implies that failure to plan for funding strategies automatically impend proper implementation.

\section{Statement of the problem}

In spite of CoU's operationalization of a retirement policy with the major aim of addressing welfare challenges of the retirees, funding has remained a major impediment to an effective implementation of the policy. This is premised on the fact that several $\mathrm{CoU}$ retirement schemes have collapsed as a result of funding challenges [12] and retired clergy do not adequately get their retirement benefits something that affect their wellbeing [13-15]. There is an outcry for $\mathrm{CoU}$ to robustly fund her retirement policy, if proper implementation is to be realised [16]. Therefore, this paper analysed the effect of funding on the $\mathrm{CoU}$ retirement policy implementation.

\section{Purpose}

The paper sought to analyse the effect of funding on $\mathrm{CoU}$ retirement policy implementation with the aim of proposing sustainable funding strategies for CoU retirement policy implementation.

\section{OBJECTIVES}

1. To analyse the relationship between funding and policy implementation.

2. To examine the effect of funding on policy implementation.

\section{Hypothesis of the study}

There is no significant relationship between retirement policy funding and implementation.

\section{Literature review}

Bodie [17] defines employer-sponsored pension plans as retirement income insurance for employees which are meant to addresses a number of questions regarding the reasons for their existence, their design, and their funding and investment policies.

The major sources of retirement income risk that a menace averse employee would like to potentially insure against are; Replacement rate inadequacy, this is the possibility that the retiree will not have enough income to maintain the same standard of living after retiring as during the preretirement year, longevity the risk that the retiree will outlive amount saved for the provision of retirement income, social Security cut the risk that the benefits provided by the Social Security retirement system will be cut before the individual reaches retirement age, investment risk- the possibility that the amount saved for retirement will be inadequate because the assets which they were invested performed poorly, inflation risk the risk that inflation will erode the purchasing power of retirement savings [17].

Bodie [17] asserts that for most people the process of planning and saving for an adequate level of retirement income is very difficult. Even the simplest models are often too complicated for the average individual to grasp. And even for people who are educated enough to understand the calculations required the discipline implement the savings plan voluntarily is often lacking. While statistics on this are hard to find, it is probably correct to say that most people do not even make rough estimates of how much they should be saving in order to insure an adequate level of income in retirement.

Employer often has better access to some of the information relevant to preparing long run financial 
plans for its employees than do the employees themselves. In particular the employer has a better knowledge of the probable path of future labor income for its employees. By providing a basic plan that saves enough to provide for replacement of the likely future stream of labor earnings, the employer can therefore save more efficiently than can the employees separately. In this connection it should be pointed out that in order for the sponsor to provide efficiently for future wage and salary replacement of its employees, it is enough to have accurate forecasts of the earnings of the group as a whole and not the individual earnings of each member of the group. It is far easier, although by no means easy, to forecast group earnings than it is to forecast an individual's future earnings [17]. According to Armstrong [18] through a retirement policy, organizations are able to regulate a smooth exit of the aging employees and ensuring that they are helped to cope up with the new environment and to eliminate the likely outcomes of this disconnection. This is mostly achievable if retirement funding is well forecast and facilitated.

This study investigated whether $\mathrm{CoU}$ has intentional programs of funding her retirement policy since such policies replace salaries and wages after retirement.

Employers who acquire a reputation for taking care of the retirement needs of their employees may find it easier to recruit and retain higher quality employees in the future. If an attitude of trust and good will towards the employer develops in the minds of the employees, then motivation and labor productivity may be enhanced. Employers therefore have some economic incentive to act in the best interests of their particularly retirement benefits like pension and gratuity [17]. Church of Uganda Provincial Human Resource Manual [19] and Church of Uganda financial Policy manual [20] stipulate that church of Uganda is to provide terminal benefits to retiring clergy in order to ensure their welfare and retain and attract competent church workers. Nevertheless several reports indicate that there is an outcry not only for the CoU's failure to fund her retirement policy, but the church is struggling to attract educated and young people for theological training hence posing a human resource crisis.

This paper has been intentional at finding out whether the current trend of $\mathrm{CoU}$ retirement funding is affecting recruitment and turnover of CoU staff in anyway.

All individuals irrespective of their work and organizational attachment history face some risk of ending up old, sick, alone, and poor [21], especially if their work retirement policy had no appropriate funding strategies to cater for their welfare. It is observed that several retirement policies do not only have issues in there formulation but they are also under funded by the same organisations which impends policy implementation and thus pausing a challenge on the welfare of the retirees. Poverty rates among the elderly are high and increase with age; they rise from a level of $17 \%$ for those aged $75-79$ to $19 \%$ for those aged 80 and over [22]. The dire socio economic situations of retirees are also evident in the kind of support they receive from family and communities in which they stay. Traditionally, the extended family's multigenerational household has always been the single most important source of care in Sub-Saharan Africa [23]. Lutala, Kwalya, Kasagila, Watongoka \& Mupenda [24] adds that Africans have always banked on the strength of traditional family solidarity. However, according to Dhemba [25], care provision by kin is strained: the potential caregivers, also being the most productive age-group of 21 to 49 [26], die of HIV/AIDS, and SubSaharan Africa remains the hardest hit. Secondly, Kaseke \& Dhemba [27] also argue that previously builtin safety-nets have been disrupted by the weakening of traditional social ties and obligations, by the emergence of new forms of socio-political control, new religions and family structures, globalization, industrialization and urbanization, all of which undermine traditional extended family systems and promote individualism and waning of gerontocracy's power and status.

Although Ncube [23] and Dhemba [25], discussed the significance of retirement policies due to the shortcomings of the traditional systems in the care for retirees, the authors left a gap on how funding issues can affect retirement policy implementation. In Nigeria, the pension scheme for the formal workers is said to be bedeviled with a lot of problems making it impossible for effective implementation [1, 28]. Problems like non regular payment of their entitlement; embezzlement of pension funds and other corrupt practices have left many older adults in financial problems. Even in the social sectors, there has been limited prioritization of older adults [29]. In Nigeria, retirement policies implementations are failed as a result of funding variables, instead focusing almost exclusively on younger adults, children and youth [30, 31].

\section{METHODOLOGY}

The study adopted a post-positivism philosophy/critical realism which is understood as a research paradigm placed between positivism and interpretivism, attempts to combine the question of "how" (understanding) which is linked to interpretivism and the "why" (explanation) which is linked to positivism approaches hence bridging the gap between the extremes [32]. Therefore, the study used both qualitative and quantitative approaches to analyze $\mathrm{CoU}$ retirement policy funding on its implementation. Most mixed studies include both quantitative and qualitative questions and indicate the logic of design. If both types of data are collected concurrently, it gives equal opportunity to each [33]. 
The study considered a total population of 380 inclusive of both retired clergy and administrators from the 6 dioceses of Buganda region that is Luweero, Kampala, Namirembe, Mukono, West Buganda and Mityana from which an estimate of 240 participants was derived comprising of 216 retired clergy and 24 administrators selected from sitting bishops, retired bishops, Archdeacons and Diocesan Secretaries [34]. From the above, a sample of 148 participants was determined using Krejcie and Morgan [35, 42] approach sample formular $\mathrm{S}=\mathrm{X}^{2} \mathrm{NP}(1-\mathrm{P})+\mathrm{d}^{2}(\mathrm{~N}-1)+\mathrm{X}^{2} \mathrm{P}(1-$ $\mathrm{P})$.

Table-1: Illustrating the: Sample frame showing category of respondents

\begin{tabular}{|l|l|l|l|}
\hline No & Category of respondents & Target Population & Sampling Technique \\
\hline 1 & Retired clergy & 216 & Random \\
\hline 2 & Administrators & 24 & Purposive \\
\hline & Total & 240 & \\
\hline
\end{tabular}

Data collection methods, the study used a set of three data collection methods, in order to collect the required data. The three methods were; documentary review, interviews and questionnaires, in order to guarantee the research principle of triangulation. This study employed questionnaires to gather quantitative data from the retired clergy with the intention of understanding their feeling about the retirement policy funding and its implementation to give a validation of what the researcher hypothesized. Amin [36] describes a questionnaire as a form consisting of interrelated questions prepared by the researcher about the research problem under investigation, based on the objectives of the study. The questionnaires contained both structured and unstructured questions.

Table-2: Data Collection Methods and Instruments

\begin{tabular}{|l|l|}
\hline Method & Instrument \\
\hline Survey & Questionnaire \\
\hline Interview & Interview guide \\
\hline Documentary review & Document checklist \\
\hline
\end{tabular}

\section{RESULTS AND DISCUSSION}

Findings revealed that Dioceses cannot financially sustain retirement superannuation hence they individually decided to offer what they desire or afford. Results of the study further revealed that out of the 6 Dioceses, it is only Kampala and Luweero that give gratuity to the retiring clergy. It is also evident that what the two dioceses give is very low compared to
National Social Security Fund and the Public Service Pension Scheme. This meant that retired clergy have to search for different sources in order to fund personal capital projects like land, house or investment which are paramount for survival of retirees. These Dioceses are also unable to provide adequate pension for the retirees inferring that $\mathrm{CoU}$ retirement policy implementation is impended by insufficient funding factors.

Table-3: Frequency distribution of Background Characteristics

\begin{tabular}{|l|l|l|l|}
\hline Variable & Description & Frequency & Percent \\
\hline Sex & Male & 72 & 80.9 \\
\hline & Female & 17 & 19.1 \\
\hline Age bracket & Total & 89 & 100.0 \\
\hline & Below 65 years & 59 & 64.8 \\
\hline & Above 65 years & 32 & 35.2 \\
\hline Marital status & Total & 91 & 100.0 \\
\hline & Married & 63 & 91.3 \\
\hline & Single & 6 & 8.7 \\
\hline Education Qualification & Total & 69 & 100.0 \\
\hline & Certificate & 28 & 36.4 \\
\hline & Diploma & 16 & 20.8 \\
\hline & Degree & 33 & 42.9 \\
\hline Status of minister & Total & 77 & 100.0 \\
\hline & Lay person & 9 & 13.4 \\
\hline & Ordained & 58 & 86.6 \\
\hline Status of service & Total & 67 & 100.0 \\
\hline & Retired & 54 & 66.7 \\
\hline & Active service & 27 & 33.3 \\
\hline Have dependents & Total & 81 & 100.0 \\
\hline & Yes & 71 & 93.4 \\
\hline & No & 5 & 6.6 \\
\hline & Total & 76 & 100.0 \\
\hline
\end{tabular}

*Total frequency less than 94 indicates non response of some respondents 
The demographic table above shows that of the 69 respondents that indicated their marital status, $91.3 \%$ were married, implying that most retired clergy have family responsibilities that mandate them to sustain an income in order to earn a living hence the need for retirement benefits . Regarding education level, out of the 77 responses, majority $(42.9 \%)$ had a degree, followed by $36.4 \%$ with a certificate and the rest were diploma holders, this meant that all CoU clergy attain formal education and they are able to read, write and interpret. $58(86.6 \%)$ of the 67 were ordained and the rest are laymen because the study majorly focused on the impact of the retirement policy implementation on retired clergy. On the matter of whether the respondents have dependents, majority $(93.4 \%)$ of the 71 that respondents had people to look after simply because they had families.

Table-4: Descriptive analysis of Funding the Retirement Policy

\begin{tabular}{|l|l|l|}
\hline & Mean & Std \\
\hline The retirement policy is funded by the province & 2.2 & 1.0 \\
\hline Every diocese makes a contribution to the policy & 2.8 & 0.9 \\
\hline Retirement policy money is raised by church commissioners & 2.7 & 1.1 \\
\hline The policy is funded every year by church commissioners & 2.5 & 1.0 \\
\hline Retirement money is kept by diocesan treasurers & 3.6 & 1.2 \\
\hline Every clergy contributes to retirement fund & 2.6 & 0.9 \\
\hline There are investments made to fund retirement at diocese & 2.8 & 1.2 \\
\hline The province invests to fund retirement of clergy & 2.4 & 1.1 \\
\hline All retired clergy get the same amount of benefits & 2.6 & 1.1 \\
\hline Aggregate Mean \& SD & 2.7 & 1.1 \\
\hline
\end{tabular}

Legend: 4.20-5.00 Very Good, 3.40-4.19 Good, 2.60-3.39 Fair, 1.80-2.59 Poor, 1.00-1.79 Very Poor

The study findings presented in Table 2 indicated that within $\mathrm{CoU}$ Buganda Dioceses the retirement policy funding is fair on part of the staff despite some sizable variations across the retired clergy at $($ Mean $=2.7, \mathrm{SD}=1.1)$. As presented in table 2, results show that the province does not fund the retirement policy and that there is no arrangement in the policy for the active clergy to make a contribution towards their retirement fund, these coupled with the dioceses low contribution lead to irregular payment and delivery of retirement benefits.

Although some dioceses like Mityana and West Buganda have made efforts to establish retirement funding projects, the church commissioners which is the investment arm of the $\mathrm{CoU}$ has not supported in initiating projects that can facilitate the retirement fund hence explaining the reason as to why there are discrepancies in the way how dioceses fund there retirement schemes. Precisely the mean of 2.7 and SD 1.1 is a depiction of Dioceses' low commitment as far as funding of the retirement policy is concerned which subsequently impede the CoU retirement policy implementation. This also explains the reason as to why there are disparities in the way how Dioceses administer the retirement benefits despite the presence of a uniform policy which should be adhered to by all the dioceses in the Province of the Church of Uganda, and as to why retired clergy receive peanut pension.

The perceptions of the respondents towards the policy implementation was as follows

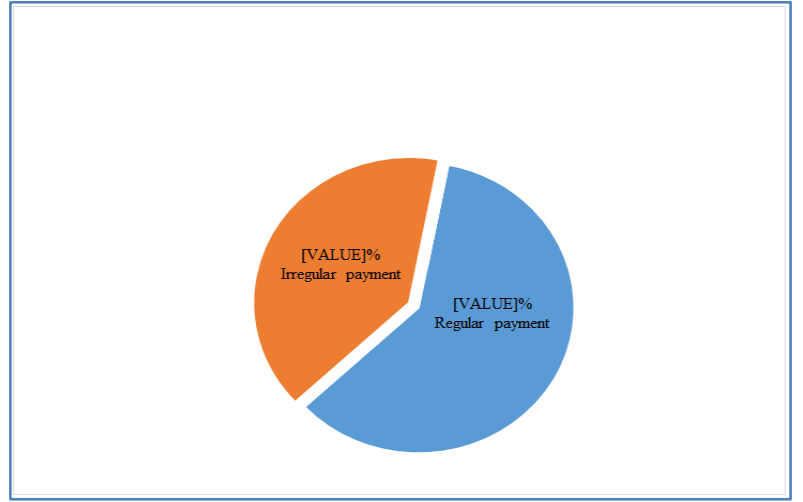

Fig-1: A pie chart showing proportion of clergy who receive regular retirement benefits

Among the respondents $60 \%$ intimated that retirement benefits were paid to them every month. Whereas $40 \%$ of the respondents indicated that they did not get payments every month. Findings revealed that the $60 \%$ aforementioned were coming from mainly urban and semi-urban areas of Kampala, Namirembe, and Mukono, save for Mityana diocese - albeit being a rural diocese - that has systematic arrangements to mobilise resources locally, for example the Noah's Ark hostel at Ndejje University that was built to contribute towards the pension project. On the other hand, the $40 \%$ mainly came from Luweero and West Buganda Dioceses which are predominantly rural and without gazetted projects to fund the retirement policy. This implies that funding factors play a big role in retirement policy implementation, since dioceses with a funding strategy met their pension plans compared to those that did not. Therefore, if at all the Church comes up with formal funding mechanisms such as that done by 
Mityana Diocese; she can be able to generate funds needed for implementing a retirement policy.

Findings in Table 2 and figure 1 agree with Karoly [35]; Patrickson \& Ranzijin [37]'s notion that there is a relationship between funding of retirement policy and implementation, this is because whenever retirement policies are underfunded policy implementers have nothing to deliver to the retirees which eventually affect their wellbeing.

The researcher concurs with Karoly [35] and the findings in Table 2 that there is a relationship between retirement policy funding and implementation, since dioceses need resources to meet the mandatory retirement benefits including medical insurance, pension and gratuity.
Administrators expressed that unless $\mathrm{CoU}$ comes up with funding measures, retirement policy shall never be implemented properly. In his words:

$\mathrm{CoU}$ can never be able to implement her retirement policy unless she ensures it's funding. The Province should come up with fundraising strategies to fund the existing schemes. For example, a week can be declared in the entire Province and the collections should be directed to a scheme developed to cater for the retired clergy, this can be supplemented with contributions either from parishes or the clergy themselves [14].

\section{Retirement policy implementation}

Table-5: Descriptive Results on the Retirement Policy Implementation in Church of Uganda, Buganda Dioceses

\begin{tabular}{|l|l|l|}
\hline Retirement Policy Implementation Aspects & Mean & Std. Deviation \\
\hline The CoU policy is responsible for the policy & 3.46 & 1.58 \\
\hline The dioceses are responsible for implementing it & 3.87 & 1.53 \\
\hline There are offices in charge of retirement policy at CoU & 2.49 & 1.18 \\
\hline There are people responsible for the policy at diocese & 2.91 & 1.33 \\
\hline Annual meetings are held to update retirees about the policy & 2.59 & 1.13 \\
\hline Each beneficiary completes retirement policy form & 2.88 & 1.32 \\
\hline Retirement policy applies to only those who retire at 65 years & 3.04 & 1.36 \\
\hline House of Bishops plays a role in retirement policy & 2.90 & 1.15 \\
\hline House of clergy plays a role in retirement policy & 3.13 & 1.28 \\
\hline House of laity plays a role in retirement policy & 3.27 & 1.16 \\
\hline Retirement benefits are paid monthly. & 3.38 & 1.31 \\
\hline Aggregate Mean\& SD & $\mathbf{3 . 0 8}$ & $\mathbf{1 . 3 0}$ \\
\hline
\end{tabular}

Legend: 4.20-5.00 Very High, 3.40-4.19 High, 2.60-3.39 Average, 1.80-2.59 Low, 1.00-1.79 Very Low

Findings in Table 3 indicate a moderate level in relation to the implementation of the retirement policy in Church of Uganda, Buganda Dioceses which equally greatly vary across the retired clergy $($ Mean $=$ 3.08, $\mathrm{SD}=1.30$ ).

The findings specifically show high responsibility for the policy by $\mathrm{CoU}$, inclusive of its implementation just as the people implementing who are highly responsible. Sometimes however, each beneficiary completes retirement policy form with the retirement policy applying to only those who retire at 65 years, with the house of Bishops sometimes playing a role in retirement policy. Table 3 also shows that sometimes the House of clergy plays a role in retirement policy just as the House of laity.

Dioceses in Buganda are part of the Province of the CoU. A diocese is represented by five members to the Provincial Assembly which is also the supreme governing body of the Church. The linear body at the diocesan level is the Diocesan synod that is also mandated to develop guidelines for every diocese. In specific reference to retirement procedures in Buganda dioceses, although all dioceses subscribe to the Province each of them remains with the liberty of implementing a policy based on a local context. For example, every diocese has different rates and approaches to generating their retirement funding (pension and gratuity), viz. $1.5 \%$ of the total collections for Namirembe, $5 \%$ of the total collections for Mityana, $2 \%$ of the total collections and $10 \%$ of Christmas for Mukono and Luweero, and 10\% of Christmas and Easter thanksgiving offertories for West Buganda. Whereas the Diocese of Kampala made her parishes to contribute 80,000 UGX per month for every clergy to a diocesan pool for pension and gratuity of the retired clergy.

It is also evident that apart from pension and gratuity, dioceses do not have extra retirement benefits like housing or medical scheme save for Kampala that is trying to develop a medical scheme [38-41].The overall implication is that dioceses adhere to the retirement policy guideline stipulated by the Province that provides gratuity and pension tailored to the local context.

The six diocesan secretaries who were interviewed on this agreed that what dioceses gave as retirement benefits could not commensurate very inadequate to sustain retirement policy. It is evident that 
Dioceses depend on what can be available to determine the pension since the Province does not stipulate specific figures. One of the Diocesan secretaries stated that:

I know that the cost of living in Kampala is high and much as some dioceses and parishes gave some little support to their retired clergy, they cannot give them what is enough. For example in spite of the pension that ranges from $350,000 /=$ to $450,000 /=$ in my diocese depending on one's period of service, the retired clergy cannot cater for utilities [14].

\section{CONCLUSION}

The study`s objective was to ascertain whether $\mathrm{CoU}$ retirement policy funding had an influence in the policy implementation. The study reported on the respondents' views on policy implementation. It was revealed by the descriptive analysis that funding was about mean of 2.7. This implied that there was low commitment in the dioceses contributed resources towards the funding of the retirement policy and hence affecting a robust implementation of the retirement policy. It was evident that there were gaps in budgeting for the policy, no adequate investments to generate revenue and individual clergy were not mandated to contribute towards their retirement scheme. It is therefore imperative that CoU should strategically initiate investment projects and establish other mechanisms of raising funds in order to facilitate the implementation of the retiree's retirement policy implementation.

\section{RECOMMENDATIONS}

The study recommended that the church commissioners should support dioceses and the Province to establish projects that would facilitate in the funding of the retirement scheme.

It is recommended that $\mathrm{CoU}$ retirement policy should be amended to adopt a contributory system paradigm in order to enable the active clergy to contribute a percentage towards a retirement scheme of their dioceses and that the province should come with measures to ensure that there are no disparities in the way dioceses administer there retirement benefits.

\section{REFERENCES}

1. Moore H. Is there a crisis in the family? UNRISD Occasional Paper: World Summit for Social Development; 1994.

2. Pillemer K, Moen P, Glasgow N, Wethington E, editors. Social integration in the second half of life. JHU Press; 2000 Nov 24.

3. Ekerdt DJ, De Viney S, Kosloski K. Profiling plans for retirement. The Journals of Gerontology Series B: Psychological Sciences and Social Sciences. 1996 May 1;51(3):S140-9.

4. Burtless G, Quinn JF. Retirement trends and policies to encourage work among older
Americans. Working Papers in Economics. 2000 Jan 1:175.

5. Quinn JF and Burkhauser RV. Retirement and Labour Force Behaviour of the Elderly. Licon Bolton Ltd. 1994.

6. Habib J, Nusberg C. Rethinking Worklife Options for Older Persons. 1990 Dec.

7. Moore KD, Robson WB, Laurin A. Canada's Looming Retirement Challenge: Will future retirees be able to maintain their living standards upon retirement?. CD Howe Institute Commentary Pension Paper. 2010 Dec 17(317).

8. Mercer JH. An Idea Retirement System. CFA Institute; 2015.

9. Amaike B. Sustainability, Livelihoods, and Quality of Life of Older Retirees in Lagos State, Nigeria.2016.

10. Obashoro O. Ageing Gracefully. Lagos, Nigeria: Concept Publications; 2010.

11. Atchley RC. A Continuity Theory of Normal Aging. The gerontologist. 1989; 29(2), 183-190.

12. Church of Uganda Directorate of Education Report; 2018.

13. Kazimba S. Archbishop and the Bishop of Kampala Enthronement charge All Saints Cathedral Nakasero; 2020.

14. Ntagali S. Archbishop's report to the House of Bishops, Church Of Uganda; 2019.

15. Bukenya KDE and Ebitu OC. Retired Bishops and their wives. 2017.

16. Church of Uganda Churchman's Diary Pocket Book; 2018.

17. Bodie Z. Pensions as retirement income insurance (No. w2917). National Bureau of Economic Research; 1989.

18. Armstrong M. Human Resource Management Practice. Gopsons papers Ltd., Noida. 2008.

19. Church of Uganda Provincial Human Resource Manual; 2009.

20. Church of Uganda financial Policy manual; 2016.

21. Wiles JL, Allen RE, Palmer AJ, Hayman KJ, Keeling S, Kerse N. Older people and their social spaces: A study of well-being and attachment to place in Aotearoa New Zealand. Social Science \& Medicine. 2009 Feb 1;68(4):664-71.

22. Attanasio O, Kitao S, Violante GL. Financing Medicare: A general equilibrium analysis. InDemography and the Economy 2010 Nov 22 (pp. 333-366). University of Chicago Press.

23. Ncube N. Pathways to institutional care for elderly indigenous Africans: navigating contours of alternatives. African Journal of Social Work. 2017 Aug 30;7(1):44-51.

24. Lutala MP, Kwalya TM, Kasagila EK, Watongoka LH, Mupenda BW. Health care seeking and financial behaviours of the elderly during wartime in Goma, Democratic Republic of Congo. African journal of primary health care $\&$ family medicine. 2010;2(1). 
25. Dhemba J. Social protection for the elderly in Zimbabwe: Issues, challenges and prospects. African Journal of Social Work. 2013;3(1):1-22.

26. Nations U. Department of Economic and Social Affairs, population division. International migration report. 2015.

27. Kaseke E, Dhemba J. Community mobilisation, volunteerism and the fight against HIV/AIDS in Zimbabwe. Research partnerships build the service field in Africa: Special issue on civic service in the Southern African development community. 2007 Mar:85-9.

28. Gesinde AM, Adekeye OA, Iruonagbe CT. Poverty and old age: The Nigerian situation.

29. Holmes R, Morgan J. Social protection in Nigeria: an overview of programmes and their effectiveness.

30. Barrientos A. Old Age, Poverty and Social Investment. Journal of International Development. 2002; 14, 1133-1141.

31. Ogwumike FO. Profile and dimension of Poverty in Nigeria. InNCEMA workshop on poverty reduction, Development policy centre, Ibadan 2001 (Vol. 3).
32. May T. Social Research Issues, Methods and Process. Buckingham: Open University press.2001.

33. Schumacher WY. Simplifying Advanced Metabolomic Data Processing; 2014.

34. Church of Uganda Provincial Standing Committee Report; 2018.

35. Karoly LA, Rogowski JA. The effect of access to post-retirement health insurance on the decision to retire early. ILR Review. 1994 Oct;48(1):103-23.

36. Amin MF. Social Science Research. Kampala: Makerere University. 2005.

37. Patrickson M and Ranzijin R. Bounded Choices in Work and Retirement in Australia. Employee Relations; 2004.

38. Namirembe Diocese Financial Guidelines; 2015

39. Mityana Diocese Financial Report. 2018.

40. Mukono Diocese House of Clergy Report; 2012

41. Luweero Diocese Board of Finance Report; 2018.

42. Krejcie RV, Morgan DW. Determining sample size for research activities. Educational and psychological measurement. 1970 Sep;30(3):60710. 